\title{
Note on Rhododendron macrostemon, Maxim.
}

\author{
Nom. Jap.-Misome-7irishima.
}

By

\section{Samuro Okubo.}

Maximowicz's description of Rhododendron macrostemon ${ }^{(1)}$ runs as follows:--" Humile, squarrose denseque dichotome ramosum, parce foliatum et microphyllum, ramulis glabratis; foliis apice ramulorum confertis anguste ellipticis, utriuque acutis apiceque apiculatis, breviter petiolatis, utrinque, subtus ad venas adpresse fusco-strigoso-pilosis subtusque glaucis reticulatis; floribus terminalibus 1-2, pedunculum cum calyce dense patule rufo-villoso-strigosum triplo superantibus; ....." But it seems to me that above characters are not constant. For in many plants of this species which I examined, the branches are generally whorled and the branchlets are, when young, densely hispid with white silvery hairs, which become afterwards reddish and ultimately dark-colored; and very old branchlets are often glabrate. The peduncle and calys are in most plants strigose with silvery white hairs, and in some with red hairs. The color of the corolla of early flowers is always carnose, and that of late flowers only is "virilulo-venosis" to use Maximowicz's worls.

I am inclined to think that this species may be a variety of $R h$. indicum or its hybrid form. The chief difference between this species and $R h$. indicum seems to be as follows:- the former has a few hairs on the back and margins of the corolla, and its stamens greatly exceed the corolla; while the latter has no hairs on the corolla, and its stamens do not generally exceed

(1) Rhododendreae Asiae Orientalis, p.39-40. 
the corolla. But in a variety of Rh. inclicum called "Shirasaki" the stamens are long and much exceed the corolla; and of ten among flowers of $R h$. indicum, Sweet. var. obtusum, Maxim., there are thos with stamens more or less exserting from the corolla. Thus, if my views are correct, the chief distinction between Rh. macrostemon and Pih. indicum lies in the fact that in one the corolla is hairy and in the other it is smooth. I may add here that Rh. macrostemon is never found wild but always in cultivation.

下二揭らタル和交い本植物, 殁狀ノ大略き記截セシ者ナリ

$$
\text { みうめきり!导 }
$$

東都, 花戶往々之レま栽コ来タ其自生，地ま不詳高少約一二尺枝狄細二ע 粗毛アリ通常輸生大始义小便毛密生大卜踓氏老枝二在りデ殆卜無毛ナり 最嫩枝い其毛銀色 枝頂

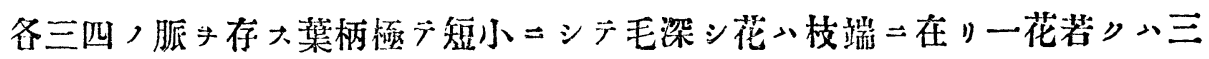
花ま着》营小ニシデ細毛密生シ且邊緣ニ長毛アリ营片貝状倒卵ナルアリ長 棈圆ナルPリ花冠鐘狀 $テ$ ナ花徑絹二牛仙、迷、全躱深紅肉色ナルキ早季



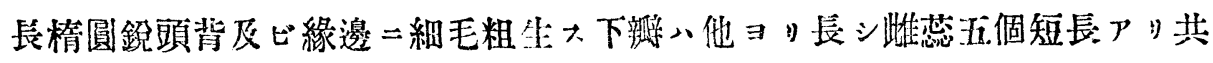
$=$ 滛 $=$ 花外 $=$ 抽出大葋 褐黄色花絲紅+口花杜八花冠二倍長シ最長



花時ハ四月下旬 $ョ$ 五月中旬二至ル

附言裳花冠雄荵共二宿存大 